\title{
SUSTAINABLE GREEN CITY LOGISTIC SOLUTION FOR THE PRAGUE AGGLOMERATION AND RETAIL CHAIN
}

\author{
Dana Sommerauerova1 ${ }^{1,}$, Jan Chocholac ${ }^{1}$, Klara Urbanova ${ }^{1}$
}

\begin{abstract}
During the 20th century, population growth and changes in the business environment also led to a change in mobility requirements. Gradually, there was an increase in transport performance in the area of passenger and freight transport. These trends are also characteristic of the 21st century, when it is also possible to talk about the fundamental development of modern information and communication technologies. The sustainable and green city logistics deals with all transport (passenger and freight) and includes material and goods flows and movements of people inside and outside the city and agglomeration with respect to the sustainability pillars. This article deals with the possibilities of supplying Lidl Česká republika v.o.s. (hereinafter Lidl) stores in Prague agglomeration from the planned logistic centre in Buštěhrad. Two scenarios are tested in terms of total carbon dioxide emissions produced: standard way of distributing goods to stores (scenario A) and sustainable and green way of distributing goods to stores (scenario B). The scientific methods and approaches are used in this article, there are: scenario analysis, vehicle routing problem with pickup and delivery with time windows and carbon dioxide emissions calculation approaches.
\end{abstract}

Keywords green logistics, city logistics, sustainability, retail chain, Prague agglomeration, vehicle routing problem with pickup and delivery with time windows, VRP Spreadsheet Solver

\section{INTRODUCTION}

The largest concentration of traffic is located within large cities and whole agglomerations. The capital of the Czech Republic and figuratively the whole Prague agglomeration is a natural centre of politics, culture and economy. A wide range of transport connections has been created in Prague, which brings above-average transport performance and high traffic intensity.

The constantly growing volume of transport performance of individual road transport and the high concentration of transport in general have a very negative effect on environmental pollution and humanity as a whole. Air pollution from sulphur dioxide has decreased in recent years, but one of the main problems remains airborne dust pollution, carbon dioxide concentrations, nitrogen oxides and vibrations. Another negative factor is excessive noise and the overall reduced quality of life of the inhabitants of the Prague agglomeration, who may perceive excessive traffic as disruptive.

The city is trying to regulate traffic with prohibitions and measures, including bus stops and parking lots for buses that allow only ten minutes to stop, as well as associated restricted entry zones, no entry zones

\footnotetext{
${ }^{1}$ University of Pardubice, Faculty of Transport Engineering, Department of Transport Management, Marketing and Logistics, Studentska 95, 532 10, Pardubice, Czech Republic

* corresponding author, phone: +420 466036 383, e-mail: dana.sommerauerova@student.upce.cz
} 
and night parking zones and driving restrictions. In the capital of the Czech Republic, some measures are already in place to help reduce traffic intensity within the city district. These measures are, for example, truck wheels for consignment delivery and dispensing boxes for picking up goods.

However, Prague has not yet addressed the city logistics strategy, but since 2015 it has been participating in the European Smart cities project "Triangulum", which is to monitor changes in selected smart and environmentally sustainable city districts in Manchester, Eindhoven and Stavanger for three years. Based on this research, Prague will develop its own plan for selected districts of the city.

It would be appropriate for companies, for example retail chains that supply cities to strive to reduce the volume of traffic and start using, for example, electric cars for the distribution of goods, which are significantly more environmentally friendly. The aim of the article is to propose measures for the supply of retail chain stores in the Prague agglomeration from the perspective of sustainable green city logistics.

\section{THEORETICAL BACKGROUND}

City logistics and transport plays an important role in the social and economic development of the city, region and state. However, in relation to the environment it is a source of emissions, noise, vibrations and causes health and safety risks and thanks to transport, there is extensive land use (Petro and Konečný, 2017). Hu et al. (2019) stated that the contradiction between the contribution of city logistics to sustainable urban development and its negative externalities is increasingly prominent. City logistics is a vital facilitator of the supply chain vitality, economic development and business prospects, which ensures the continual and stable operation of large-scale freight transport activities between suppliers and consumers in urban areas (Crainic et al., 2004; Taniguchi et al., 2003). The increase in demand for agglomeration distribution services, according to Hu et al. (2019), caused by the development of e-business and the increase of agglomeration consumption capacity has placed a great burden to:

- agglomeration mobility (e.g., congestion, low accessibility and inefficiency) (Anderson et al., 2005),

- the environment (e.g., visual intrusion, greenhouse gas emission and resource waste) (Behrends, 2016),

- social welfare (e.g., noise, accident and public health) (Kin et al., 2017),

- governance (e.g., informal freight sector, land scarcity and uncontrolled sprawl) (Kin et al., 2017).

Obviously, the duality of city logistics has brought challenges to human health and the quality of life (Hu et al., 2019; Quak and de Koster, 2009). Sustainable development and sustainability is an important factor in development of individual economies. Litman (2008) states that the concept of sustainable development is built on three pillars: economic, environmental and social.

Transport is a vital enabler of several sustainable development goals (hereinafter SDGs). It contributes strongly to the SDGs regarding economic development, industry and small and medium enterprises, as well as trade and investment. Consequently, it also helps achieve the SDGs that aim to promote employment and well-being, and to reduce inequalities and exclusion. Meanwhile, transport presents many challenges with respect to the SDGs, such as the need to reduce climate and environmental impacts, to improve transport systems and traffic safety, and to manage concerns related to jobs and decent work. (Douša, 2019)

Many authors pay attention in the field of city logistics, especially the issue of warehouse location, for example Kudláčková and Němec (2020). They stated that the selection of a suitable location for the location of a warehouse or distribution centre is one of the most important parts of managerial 
decision-making, as it has a direct impact on the effective management of supply chains (Kudláčková and Němec, 2020).

Other experts focus on the issue of last mile delivery within the city of logistics, because according to Lazarević and Dobrodolac (2020) last-mile delivery is one of the most sensitive phases to organize in the postal process from the perspective of city logistics. The traditional approach at this stage involves the use of road transport, which has a significant impact on the sustainability of the system, both financially and environmentally. Namely, it is necessary for the vehicle fleet of postal companies to be extensive, which implies the existence of a large number of different means of transport. (Lazarević and Dobrodolac, 2020)

Due to the fact, that the issue of shared economy is currently a very topical theme in many sectors of national economy. In the field of transport, it is possible to observe the use of some principles of shared economy, especially in the context of sharing capacity of cars in passenger transport (BlaBlaCar, Zipcar, DriveNow etc.). Taking into account the situation where the number of transported parcels is growing year-on-year, there is space for using principles of shared economy in ensuring the transport of parcels within city logistics. (Novotná et al., 2020)

Furthermore, there are many scientific articles that deal with the implementation of various restrictions or prohibitions within the city of logistics, for example traffic regulation in selected city centres based on urban electronic toll (Beňová et al., 2019).

\section{METHODS}

The following scientific methods and approaches are used in this article, there are: scenario analysis (subchapter 3.1), vehicle routing problem with pickup and delivery with time windows (subchapter 3.2) and carbon dioxide emissions calculation approaches (subchapter 3.3).

\subsection{Scenario analysis}

Scenario analysis is a scientific method conducted to analyse the impacts of possible future events on the system performance by taking into account several alternative outcomes, i.e., scenarios, and to present different options for future development paths resulting in varying outcomes and corresponding implications (Balaman, 2019). Scenario analysis is the process of forecasting the expected value of a performance indicator, given a time period, occurrence of different situations, and related changes in the values of system parameters under an uncertain environment (Balaman, 2019).

This article is focused on the retail chain Lidl and supply of stores in the Prague agglomeration. In June 2019, the construction of a new logistic centre of the Lidl Company began in Buštěhrad near Kladno. The building is being built in the former steelworks complex. With its storage area (almost $60000 \mathrm{~m}^{2}$ ), the logistic centre will be one of the largest in Europe and will create the capacity needed to supply up to 90 stores. One third of the area of this centre will have a regulated temperature for refrigerated and fresh goods. (ČTK, 2019)

The location of the logistic centre, according to Lidl (2020), is in the strategic vicinity of Prague between the D6 motorway and the R7 expressway with a connection to the Prague ring road and the D5 motorway. The logistic centre with a storage hall, in which up to 47000 pallets can be placed, will be the fifth logistics centre of the Lidl Company. The construction will be completed in 2021.

There are a total of $38 \mathrm{Lidl}$ stores in Prague agglomeration and its vicinity. The location of the stores is shown in Fig. 1. The article deals with the supply of these stores from the new logistic centre in Buštěhrad. Two supply scenarios will be compared: scenario A and scenario B. 


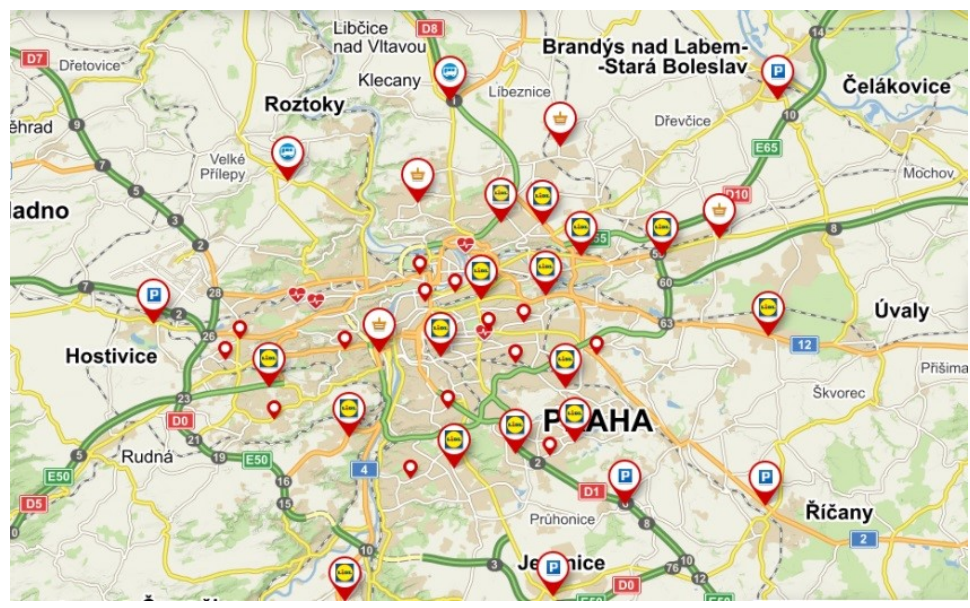

Fig. 1 Lidl stores in the Prague agglomeration and its vicinity; source: Mapy (2020)

Two possible scenarios are analysed:

- scenario A: standard way of distributing goods to stores (subchapter 3.1.1),

- scenario B: sustainable and green way of distributing goods to stores (subchapter 3.1.2).

These scenarios will be evaluated in terms of:

- total carbon dioxide $\left(\mathrm{CO}_{2 \mathrm{e}}\right)$ emissions produced within scenarios for a certain period of time,

- emission savings $\left(\mathrm{CO}_{2 \mathrm{e}}\right)$ converted to financial value (EUR) for a certain period of time.

\subsubsection{Scenario A in detail}

Scenario A is based on the standard method of distribution of all goods from the logistic centre in Buštěhrad to stores in Prague agglomeration and its vicinity using only road freight transport (diesel engine).

\subsubsection{Scenario B in detail}

Scenario B, which is in line with the sustainable green measures of city logistics, is based on the involvement of rail freight transport in the distribution of goods from the logistic centre in Buštěhrad to stores in Prague agglomeration and its vicinity.

In scenario B, refrigerated and frozen goods are delivered from the logistic centre in Buštěhrad to 38 stores using road freight transport (electric trucks). Other goods are transported from the logistic centre by rail (diesel locomotive) to a selected station in Prague and then transported by electric trucks to 38 Lidl stores.

\subsection{Vehicle routing problem with pickup and delivery with time windows}

The algorithm of heuristic method for vehicle routing problem with pickup and delivery with time windows and VRP Spreadsheet Solver (Microsoft Excel Workbook used to test both scenarios) are presented within this subchapter. Algorithm of heuristic method for Vehicle routing problem with pickup and delivery with time windows according to Desaulniers et al. (2002) uses these types of variables: binary flow variables $\mathrm{x}_{\mathrm{ijk}}$, time variables $\mathrm{T}_{\mathrm{ik}}$ (specifying when vehicle $\mathrm{k}$ starts the service at node $i \in V_{k}$ ) and variables $L_{i k}$ giving the load of vehicle $k$ after the service at node $i \in V_{k}$ has been completed. The formulation of Vehicle routing problem with pickup and delivery with time windows according to Desaulniers et al. (2002) is as follows formulas 1-15:

$$
\min \sum_{k \in K} \sum_{(i, j) \in A_{k}} c_{i j k} x_{i j k},
$$

subject to

$$
\sum_{k \in K} \sum_{j \in N_{k} \cup\{d(k)\}} x_{i j k}=1 ; \forall i \in P,
$$




$$
\begin{gathered}
\sum_{j \in N_{k}} x_{i j k}-\sum_{j \in N_{k}} x_{j, n+i, k}=0 ; \forall k \in K, i \in P_{k}, \\
\sum_{j \in P_{k} \cup\{d(k)\}} x_{o(k), j, k}=1 ; \forall k \in K, \\
\sum_{i \in N_{k} \cup\{o(k)\}} x_{i j k}-\sum_{i \in N_{k} \cup\{d(k)\}} x_{i j k}=0 ; \forall k \in K, j \in N_{k}, \\
\sum_{i \in D_{k} \cup\{o(k)\}} x_{i, d(k), k}=1 ; \forall k \in K, \\
x_{i j k}\left(T_{i k}+s_{i}+t_{i j k}-T_{j k}\right) \leq 0 ; \forall k \in K,(i, j) \in A_{k}, \\
a_{i} \leq T_{i k} \leq b_{i} ; \forall k \in K, i \in V_{k}, \\
T_{i k}+t_{i, n+i, k} \leq T_{n+i, k} ; \forall k \in K, i \in P_{k}, \\
x_{i j k}\left(L_{i k}+l_{j}-L_{j k}\right)=0 ; \forall k \in K,(i, j) \in A_{k}, \\
l_{i} \leq L_{i k} \leq C_{k} ; \forall k \in K, i \in P_{k}, \\
0 \leq L_{n+i, k} \leq C_{k}-l_{i} ; \forall k \in K, n+1 \in D_{k}, \\
L_{o(k), k}=0 ; \forall k \in K, \\
x_{i j k} \geq 0 ; \forall k \in K,(i, j) \in A_{k}, \\
x_{i j k} b i n a r y ; \forall k \in K,(i, j) \in A_{k} .
\end{gathered}
$$

The linear objective function (1) minimizes the total travel cost. Constraints (2-3) impose that each request is served exactly once and by the same vehicle. Constraints (4-6) characterize a multi-commodity flow structure and ensure that each vehicle $\mathrm{k}$ starts from its origin depot $\mathrm{o}(\mathrm{k})$ and terminates its route at its destination depot $\mathrm{d}(\mathrm{k})$. Compatibility requirements between routes and schedules are handled by constraints (7) and (8) are the time window constraints. For each request, constraints (9) force the vehicle to visit the pickup node before the delivery node. Constraints (10) express the compatibility requirements between routes and vehicle loads, while (11-12) the vehicle dependent capacity intervals at pickup and delivery nodes. The initial vehicle load is imposed by (13), and no negativity and binary requirements are given by (14-15). Constraint sets (3) through (15), as well as the objective function, are separable for each vehicle $\mathrm{k} \in \mathrm{K}$. (Desaulniers et al., 2002)

The algorithm for Vehicle routing problem with pickup and delivery with time windows is solved in the Microsoft Excel workbook VRP Spreadsheet Solver which is an open source unified platform for representing, solving and visualizing the results of Vehicle Routing Problems. VRP Spreadsheet Solver uses public Geographical Information Systems (Bing Maps) and metaheuristics. The author of the "VRP Spreadsheet Solver" is Güneş Erdoğan and its scientific area covers exact and heuristic optimization methods, ambulance location problems, traveling salesman problems, vehicle routing problems and scheduling problems. (Güneş, 2018)

\subsection{Carbon dioxide emissions calculation approaches}

Two emission calculators are used to calculate carbon dioxide emissions in tested scenarios, there are: Kalogemis (2020) designed by the Faculty of Transport Engineering, University of Pardubice as part of contract research for ŠKODA AUTO a.s. and Ecotransit (2020) designed by independent scientific institutes (Ifeu, Infras and Fraunhofer IML).

Currently, there are three main approaches to measuring energy consumption and produced emissions according to Eriksson and Nielsen (2014):

- Well-to-Wheel (sum of total Well-to-Tank and Tank-to-Wheel) - an approach based on the monitoring of energy consumption and associated emissions production that covers the whole process from the generation of electricity or fuel, through the supply to the appropriate transport means through the distribution network, to the consumption associated 
with the operation of the means of transport. This approach is based on the sum of Tank-to-Wheel and Well-to-Tank values.

- Well-to-Tank - energy consumption and production of emissions related to the production of energy or fuel, the indicator covering all activities from the extraction of raw materials through the production of energy or fuel, up to the supply to the respective means of transport through the distribution network. The indicator does not include the transport mode.

- Tank-to-Wheel - energy consumption and production of emissions related to the operation of the means of transport. The indicator does not include the next life cycle of the fuel or the transport means.

The Well-to-Wheel approach is used for the calculation of total carbon dioxide $\left(\mathrm{CO}_{2 \mathrm{e}}\right)$ emissions produced within both tested scenarios.

\section{RESULTS}

Two possible scenarios are analysed:

- scenario A: standard way of distributing goods to stores (subchapter 4.1),

- scenario B: sustainable and green way of distributing goods to stores (subchapter 4.2).

\subsection{Scenario A}

In scenario A, all goods are transported by road trucks from the Buštěhrad logistic centre to 38 Lidl stores. The prerequisite for this scenario is a homogeneous vehicle fleet consisting of road trucks with a maximum load weight of $24000 \mathrm{~kg}$, the emission standard for vehicles is EURO 6. In general, 33 euro pallets can be loaded into trucks. According to experience from an expert in the field, however, it follows that due to poor storage of pallets, a maximum of 32 euro pallets or other objects of the appropriate size are usually loaded into the truck.

Information for the construction of this scenario was obtained from an expert in the field. The prerequisites for supply are as follows. Some stores are supplied 5 times, 6 times but also 7 times a week. The calculation assumes an average of 6 deliveries of goods per week from the logistic centre to one store. Each store will receive 10 to 40 pallet places per day as part of the distribution of goods. One pallet place occupies an area of $800 \times 1200 \mathrm{~mm}$. This pallet place can be filled with a pallet or e.g. a thermo-container, etc.

The average of pallet places distributed daily to one store is 20 pallet places, of which 15 form the so-called dry colonial. Dry colonial refers to goods that are not refrigerated, frozen and do not have to maintain a special temperature regime. These include, for example, drinks, pasta, drugstores, confectionery, tea and coffee. When driving from stores back to the logistic centre, return logistic objects will be transported, including returnable packaging, claimed goods, pressed paper and plastic, pallets, thermos-containers, etc. In this scenario, an average of 12 pallet places containing reverse logistic objects, which is must be taken from each store within one shipment of goods back to the logistic centre.

The delivery simulation is performed using the VRP Spreadsheet Solver tool, which solves the so-called task of vehicle routing problem with pickup and delivery with time windows. The time window means the time at which the goods must be shipped to the stores, i.e. from 1:00 to 7:00 o'clock.

The simulation of scenario A is created with the following assumptions:

- 1 depot (logistic centre Buštěhrad) $\rightarrow 38$ Lidl stores,

- 20 pallet places of goods are distributed to one store,

- 12 pallet places with reverse logistic objects are taken back,

- homogeneous fleet, one vehicle capacity: 32 pallet places, 
- the fastest driving route,

- vehicles return to the depot,

- time window of stores for the import of goods: from 1:00 to 7:00 o'clock,

- the average loading and unloading time at the store, including administration, is 40 minutes.

This input data has been entered into the VRP Spreadsheet Solver that built an origin-destination matrix and it has calculated the most suitable solution for pickup and delivery problem with time windows. The solution is as follows: a total of 13 vehicles are needed for pickup and delivery. The vehicles will cover a total of $1899.38 \mathrm{~km}$ per day and a total of $11396.28 \mathrm{~km}$ per week. The visualization of the distribution from the logistic centre to the individual stores is shown in Fig. 2. One colour curve corresponds to one roundabout delivery.

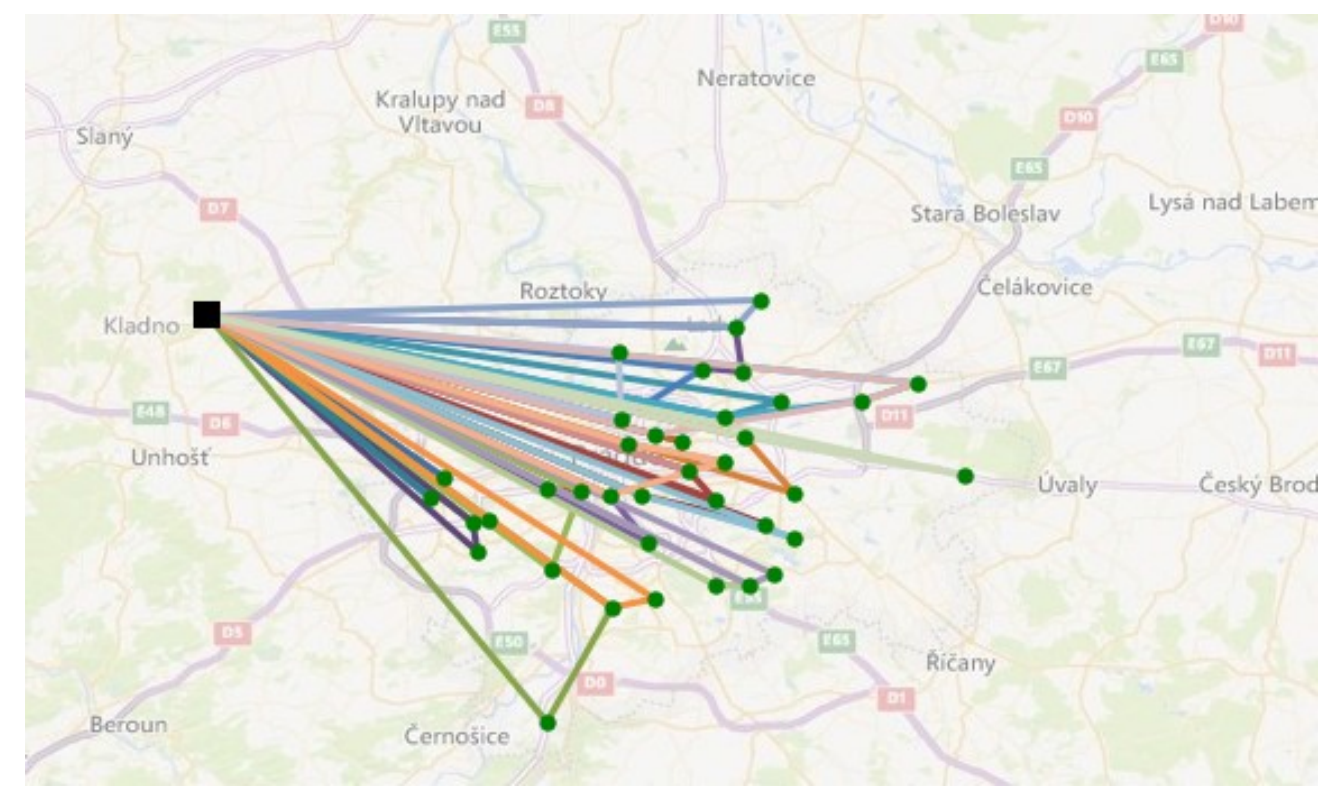

Fig. 2 Visualization of distribution of goods from the logistic centre to stores; source: Güneş (2018)

The carbon dioxide emissions of scenario $A$ are calculated using an emissions calculator Kalogemis (2020). The assumptions for the calculation of emissions produced during transport are as follows:

- megatrailer without the use of trailers, emission class EURO 6,

- maximum load weight $24000 \mathrm{~kg}$, maximum load volume $100 \mathrm{~m}^{3}$,

- according to an expert in the field, the weight of one pallet, including goods, is assumed to be $500 \mathrm{~kg}$,

- on average, 28 pallets or similar objects are loaded into the vehicle,

- weekly transport distance $11396 \mathrm{~km}$.

The value of total produced carbon dioxide emissions is $11.08990 \mathrm{tCO}_{2 \mathrm{e}}$ per week and the financial value of $\mathrm{CO}_{2}$ emissions calculated for weekly shipments is $1996.18 €$ (Kalogemis, 2020).

\subsection{Scenario B}

In this scenario B, refrigerated and frozen goods from the logistic centre in Buštěhrad are transported directly to 38 stores using electric trucks. The transport of other goods, the so-called dry colonial, is carried out from Buštěhrad with partial use of railway transport. It is necessary to choose the most suitable station with regard to the location of the stores to which the goods will be transported by rail and the technological solution. Subsequently, the goods from the selected railway station will be delivered to stores using electric trucks. 
The most suitable railway station in Prague for transhipment of goods from railway transport to road transport is the station Prague-Malešice. This assumption is also confirmed by the fact that the sum of one-way distances between analysed Prague railway stations and all 38 stores is the smallest for this station.

The Habbillnss 55 will be used to transport the goods. The Habbillnss 55 is a four-axle covered wagon with sliding side walls and adjustable interior partitions to divide the space. This wagon is especially suitable for palletized goods, bulk and piece shipments. The loading length of this wagon is $21200 \mathrm{~mm}$, the loading width is $2840 \mathrm{~mm}$. The Habbillnss 55 can transport 60 euro pallets $(800 \times 1200 \mathrm{~mm})$ and the maximum load weight is $30000 \mathrm{~kg}$. (ČD Cargo, 2020a)

Based on the transport connection planner and the distances of ČD Cargo (2020b), it was found that the train from Buštěhrad to the Prague-Malešice station will travel $50 \mathrm{~km}$. Six times a week, it is necessary to transport an average of 15 pallet places of dry groceries to 38 Lidl stores. In total, this is 570 pallets per day. The Habbillnss 55 can transport 60 pallets, which means that 10 rail wagons are needed for the daily transport of goods, with $30000 \mathrm{~kg}$ of cargo being loaded in one rail wagon.

The carbon dioxide emissions of scenario B (railway transport) are calculated using an emissions calculator Kalogemis (2020). The assumptions for the calculation of emissions produced during transport are as follows:

- railway transport, diesel traction,

- material transport, Habbillnss 55,

- 10 railway wagons, weight of transported cargo $30000 \mathrm{~kg} / 1$ wagon,

- distance $50 \mathrm{~km}$,

- transport with subsequent use of the transport unit.

The value of total produced carbon dioxide emissions is $2.1732 \mathrm{tCO}_{2 \mathrm{e}}$ per week and the financial value of $\mathrm{CO}_{2}$ emissions calculated for weekly shipments is $391.20 €$ (Kalogemis, 2020).

The transport of goods from the Prague-Malešice station to individual stores will be carried out using electric trucks. The selected vehicle is the MAN TGM eTruck, which meets all the requirements for the delivery of goods. The delivery simulation from the Prague-Malešice station is performed using the VRP Spreadsheet Solver tool in the same way as in the previous case. The visualization of the distribution from the Prague-Malešice station to the individual stores is shown in Fig. 3.

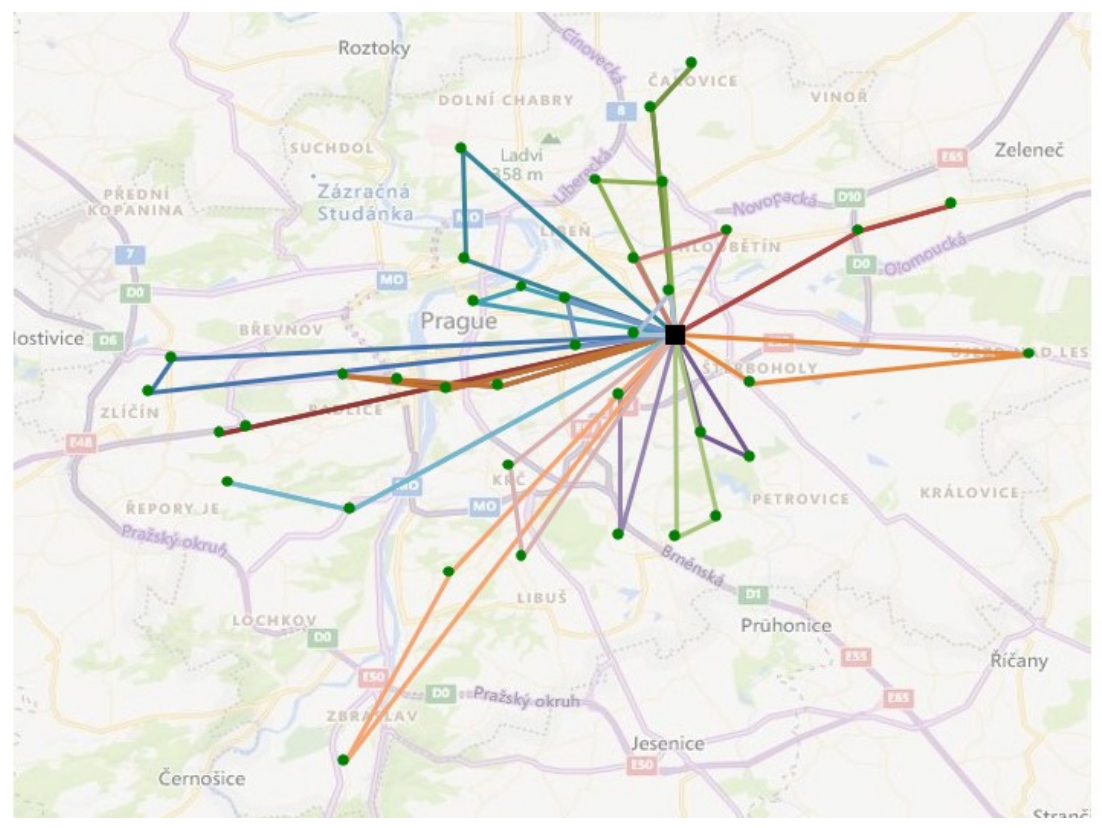

Fig. 3 Visualization of distribution of goods from the Prague-Malešice station to stores; source: Güneş (2018) 
The vehicles will cover a total of $426 \mathrm{~km}$ in one day. Assuming that the stores are supplied on average 6 times a week, it is $2556 \mathrm{~km}$ in total.

Carbon dioxide emission production for an electric truck can be calculated using the Ecotransit (2020) calculator. Prerequisites for calculating emissions produced during transport:

- an average of 28 pallets are loaded, the weight of one pallet is $500 \mathrm{~kg}$, so the weight of the load is $14000 \mathrm{~kg}$,

- electric vehicle, EURO 6, empty journeys 0\%,

- distance $2556 \mathrm{~km}$.

The value of total produced carbon dioxide emissions is $3.06 \mathrm{tCO}_{2 \mathrm{e}}$ per week according to Ecotransit (2020).

To complete this scenario, it is necessary to calculate how many kilometres electric trucks will travel from the logistic centre in Buštěhrad directly to 38 stores for the distribution of refrigerated and frozen food and food for which a special temperature regime must be observed. The calculation is again performed based on the VRP Spreadsheet Solver tool in the same way as in the previous case. A total of 2 vehicles are needed for pickup and delivery (vehicles perform three to four turns). The important information is that electric vehicles will cover $638.93 \mathrm{~km}$ in one day and 3,833.58 $\mathrm{km}$ in one week (assumption of 6 deliveries per week). The visualization of the distribution of refrigerated and frozen food and food for which a special temperature regime must be observed from the logistic centre Buštěhrad to the individual stores is shown in Fig. 4.

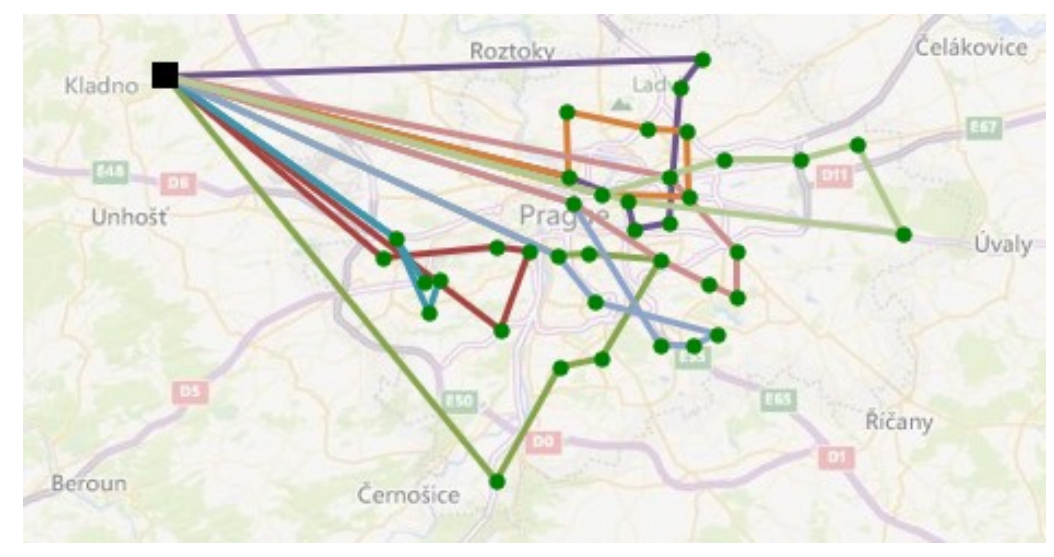

Fig. 4 Visualization of distribution of special temperature regime goods from the logistic centre to stores; source: Güneş (2018)

Carbon dioxide emission production for an electric truck can be calculated using the Ecotransit (2020) calculator. The value of total produced carbon dioxide emissions is $2.76 \mathrm{tCO}_{2 \mathrm{e}}$ per week according to Ecotransit (2020).

\subsection{Scenario A and B comparison}

In scenario A, where all goods are distributed by standard road transport from the logistic centre in Buštěhrad to $38 \mathrm{Lidl}$ stores, the weekly production of carbon dioxide emissions is $11.08990 \mathrm{tCO}_{2 \mathrm{e}}$ and the annual production of carbon dioxide emissions is $576.678 \mathrm{tCO}_{2 \mathrm{e}}$.

The total carbon dioxide emissions production in scenario B consists of the following emissions:

- emissions produced during the transport of dry groceries using rail transport from the logistic centre in Buštěhrad to the station Prague-Malešice $\left(2.1732 \mathrm{tCO}_{2 \mathrm{e}}\right.$ per week, 113.0064 $\mathrm{tCO}_{2 \mathrm{e}}$ per year), 
- emissions produced during the transport of dry groceries by electric road trucks from the Prague-Malešice station to $38 \mathrm{Lidl}$ stores (3.06 $\mathrm{tCO}_{2 \mathrm{e}}$ per week, $159.12 \mathrm{tCO}_{2 \mathrm{e}}$ per year),

- emissions produced during the transport of refrigerated, frozen and other goods subject to a special temperature regime from Buštěhrad by electric road trucks directly to 38 stores (2.76 $\mathrm{tCO}_{2 \mathrm{e}}$ per week, $143.52 \mathrm{tCO}_{2 \mathrm{e}}$ per year).

In scenario B, the weekly production of carbon dioxide emissions is $7.9932 \mathrm{tCO}_{2 \mathrm{e}}$ and the annual production of carbon dioxide emissions is $415.6464 \mathrm{tCO}_{2 \mathrm{e}}$. The total carbon dioxide emissions comparison is presented in Tab. 1.

Tab. 1 Scenario comparison; source: authors

\begin{tabular}{lcccc}
\hline Scenario & A & B & Difference \\
\hline $\begin{array}{l}\text { Annual production } \\
\text { of } \mathrm{CO}_{2} \text { emissions }\end{array}$ & {$\left[\mathrm{tCO}_{2 \mathrm{e}}\right]$} & 576.6780 & 415.6464 & -161.0316 \\
\hline
\end{tabular}

In the case of partial use of rail transport and electric trucks for the distribution of goods to retail stores (scenario B), $161.0316 \mathrm{tCO}_{2 \mathrm{e}}$ emissions would be saved per year compared to the standard distribution of goods using only road freight transport (scenario A).

The emission calculator Kalogemis (2020) enable to recalculate the saved $\mathrm{CO}_{2 \mathrm{e}}$ emissions on the basis of a recommendation from the German office Das Umweltbundesamt to a financial value corresponding to the saved amount of carbon dioxide emissions. Emission savings (161.0316 $\mathrm{tCO}_{2 \mathrm{e}}$ per year) corresponds to financial savings of $28985.76 €$ per year.

\section{CONCLUSIONS}

The topic of sustainable green city logistics solutions for the big cities and whole agglomeration is very current. The aim of the article was to propose measures for the supply of retail chain stores in the Prague agglomeration from the perspective of sustainable green city logistics.

Two scenarios were presented within the article: scenario A (standard way of distributing goods to stores) and scenario B (sustainable and green way of distributing goods to stores). In the case of partial use of rail transport and electric trucks for the distribution of goods to retail stores (scenario B), $161.0316 \mathrm{tCO}_{2 \mathrm{e}}$ emissions would be saved per year compared to the standard distribution of goods using only road freight transport (scenario A). However, it should also be mentioned that high investment and operating costs are also associated with this measures, as the purchase price of electric trucks is higher than for conventional diesel lorries. However, truck operators will save up to one euro per kilometre thanks to cheap charging. Electric trucks are used mainly due to subsidies and tax breaks. Subsidies could be a suitable motivation for companies. These subsidies are for example provided by thematic operational programs. It would therefore be appropriate for Prague and whole Prague agglomeration to try to motivate companies to use electric trucks for supplies that are significantly more environmentally friendly.

\section{Acknowledgements}

This paper is published within the solution of the scientific research project of the University of Pardubice no. SGS_2020_010. The authors are grateful for their support.

\section{References}

Anderson, S., Allen, J. and Browne, M. 2005. Urban logistics - How can it meet policy makers' sustainability objectives? Journal of Transport Geography, 13(1), pp. 71-81. <https://doi.org/10.1016/j.jtrangeo.2004.11.002> 
Balaman, S. Y. 2019. Decision-Making for Biomass-Based Production Chains: The Basic Concepts and Methodologies. New York: Academic Press.

Behrends, S. 2016. Recent developments in urban logistics research - A review of the proceedings of the international conference on city logistics 2009-2013. Transportation Research Procedia, 12, pp. 278-287. <https://doi.org/10.1016/j.trpro.2016.02.065>

Beňová, D., Gnap, J. and Harantová, V. 2019. Regulácia dopravy do centra mesta na základe mestského elektronického mýta. Perner's Contacts, 14(3), pp. 5-13. $<$ https://pernerscontacts.upce.cz/index.php/perner/article/view/420>

Crainic, T. G., Ricciardi, N. and Storchi, G. 2004. Advanced freight transportation systems for congested urban areas. Transportation Research Part C: Emerging Technologies, 12(2), pp. 119-137. <https://doi.org/10.1016/j.trc.2004.07.002>

ČD Cargo. (C) 2020a. Katalog železničních nákladních vozů ČD Cargo. [Online]. Available at: https://www.cdcargo.cz/katalog-nakladnich-vozu [Accessed: 2020, September 3].

ČD Cargo. (C) 2020b. Přepravní spojení a vzdálenosti. [Online]. Available at: https://www.cdcargo.cz/prepravni-spojeni-a-tarifni-vzdalenosti?inheritRedirect=true [Accessed: 2020, September 8].

ČTK. (C) 2019. Lidl začal u Kladna stavět obří sklady. Práci zde najde pět set lidí. [Online]. Available at: https://zpravy.aktualne.cz/ekonomika/lidl-zacal-u-kladna-stavet-obri-sklady-praci-zde-najde-pets/r 03149b268d2711e98a200cc47ab5f122/ [Accessed: 2020, April 5].

Desaulniers, G., Desrosiers, J., Erdmann, A., Solomon, M.M. and Soumis, F. 2002. VRP with Pickup and Delivery. In Discrete Mathematics and Applications: The Vehicle Routing Problem, pp. 225-242. Philadelphia: Society for Industrial and Applied Mathematics. <https://doi.org/10.1137/1.9780898718515>

Douša, M. 2019. Úloha dopravy při plnění cílů udržitelného rozvoje. Perner's Contacts, 14(1), pp. 47-57. <https://pernerscontacts.upce.cz/index.php/perner/article/view/396>

EcoTransIT. (C) 2020. Emission calculation. [Online]. Available at: https://www.ecotransit.org/calculation.en.html [Accessed: 2020, October 6].

Eriksson, L. and Nielsen, L. 2014. Modelling and control of engines and drivelines. Chennai: John Wiley and Sons. <https://doi.org/10.1002/9781118536186.fmatter>

Güneș, E. (C) 2018. VRP Spreadsheet Solver. [Online]. Available at: http://people.bath.ac.uk/ge277/index.php/vrp-spreadsheet-solver/ [Accessed: 2020, October 13].

Kalogemis. (C) 2020. Kalkulátor logistických emisí. [Online]. Available at: https://kalogemis.upce.cz/epsilon/silnicni.php [Accessed: 2020, October 24].

Kin, B., Verlinde, S. and Macharis, C. 2017. Sustainable urban freight transport in megacities in emerging markets. Sustainable Cities and Society, 32, pp. 31-41. <https://doi.org/10.1016/j.scs.2017.03.011>

Kudláčková, N. and Němec, M. 2020. Možnosti vytvoření skladové sítě v logistice poslední míle. Perner's Contacts, 15(1). <https://doi.org/10.46585/pc.2020.1.1540>

Lazarević, D. and Dobrodolac, M. 2020. Sustainability trends in the postal systems of last-mile delivery. Perner's Contacts, 15(1). <https://doi.org/10.46585/pc.2020.1.1547>

Lidl. (C) 2020. Největší logistické centrum Lidlu, Buštěhrad. [Online]. Available at: https://kariera.lidl.cz/cs/Bustehrad.htm [Accessed: 2020, April 4].

Litman, T. A. 2008. Sustainable transportation indicators. [Online]. Available at: https://www.vtpi.org/sustain/sti.pdf [Accessed: 2020, September 28]. 
Mapy. $\quad$ C $2020 . \quad$ Mapy. $\quad$ Online]. Available at: https://mapy.cz/zakladni?x=16.7551000\&y=49.9163000\&z=11 [Accessed: 2020, October 2].

Novotná, M., Švadlenka, L. and Gottwald, D. 2020. Hodnocení relevantnosti implementace principů sdílené ekonomiky při přepravě zásilek v České republice. Perner's Contacts, 15(1). <https://doi.org/10.46585/pc.2020.1.1551>

Petro, F. and Konečný, V. 2017. Calculation of emissions from transport services and their use for the internalisation of external costs in road transport. Procedia Engineering, 192, pp. 677-682. <https://doi.org/10.1016/j.proeng.2017.06.117>

Quak, H. J. and de Koster, M. B. M. 2009. Delivering Goods in Urban Areas: How to Deal with Urban Policy Restrictions and the Environment. Transportation Science, 43(2), pp. 211-227. <https://doi.org/10.1287/trsc.1080.0235>

Taniguchi, E., Thompson, R. G. and Yamada, T. 2003. Predicting the effects of city logistics schemes. Transport Reviews, 23(4), pp. 489-515. <https://doi.org/10.1080/01441640210163999> 